\title{
References
}

Aldinger, H. 1935: Geologische Beobachtungen im oberen Jura des Scoresbysundes (Ostgrönland). Meddr Gronland 99, 1, 128 pp.

Birkelund, T., Håkansson, E. \& Surlyk, F. (in press): New finds of Bathonian, Callovian, and Oxfordian ammonites in northern Jameson Land, East Greenland. Bull. geol. Soc. Denmark 20, 240-259.

Callomon, J. H. 1959: The ammonite zones of the Middle Jurassic beds of East Greenland. Geol. Mag. 96, 505-513.

Callomon, J. H. 1961: The Jurassic System in East Greenland. In Raasch, G. O. (editor): Geology of the Arctic 1, 258-268. Toronto U. P.

Callomon, J. H. 1970: Geological map of Carlsberg Fjord - Fossilbjerget area. Meddr Grønland 168, 4, 10 pp.

Grasmück, M. \& Trümpy, R. 1969: Triassic stratigraphy and general geology of the country around Fleming Fjord (East Greenland). Meddr Gronland 168, 2, 1-71.

Rosenkrantz, A. 1929: Preliminary account of the geology of the Scoresby Sound district. Meddr Gronland 73, 2, 135-154.

Spath, L. F. 1935: The Upper Jurassic invertebrate faunas of Cape Leslie, Milne Land. I: Oxfordian and Lower Kimmeridgian. Meddr Grønland 99, 2, 82 pp.

Spath, L. F. 1936: The Upper Jurassic invertebrate faunas of Cape Leslie, Milne Land. II: Upper Kimmeridgian and Portlandian. Meddr Grønland 99, 3, 180 pp.

Watt, S. W. 1970: Preliminary report of the mapping of the basalt area, south Scoresby Sund. Rapp. Gronlands geol. Unders. 30, 30-37.

\section{GEOELECTRICAL SOUNDINGS IN HOLSTEINSBORG}

\section{K. Klitten and O. B. Olesen}

In the summer of 1969 a geoelectrical sounding programme was started in Holsteinsborg by the second author with equipment borrowed from the Institute for Applied Geology, the Technical University of Denmark. The following summer the work was followed up by further soundings at selected localities in the same area based on the results from the first summer.

The interpretation of data from the investigation is being carried out in cooperation with the first author from the Institute for Applied Geology.

The scope of the work was the evaluation of geoelectrical soundings in preliminary engineering geological investigations, especially delineation and depth of permafrost. Therefore Holsteinsborg was chosen as the working site, because within this town areas both with and without permafrost are present. Another advantage was the great number of boreholes, made by the Technical Organisation of Greenland, which gave a good basis for correlation.

The soundings were mostly carried out as point-profiles and only a single lineprofile was measured. Altogether 18 profiles were measured; 6 of these were measured 
orthogonally with the electrodes in both Wenner and Schlumberger configuration, the rest only with Schlumberger configuration.

In so far as the results have been interpreted to date, the geoelectrical sounding method appears to be able to give relevant qualitative information in preliminary engineering geological investigation. Detailed quantitative information about the actual stratification can apparently only be obtained with a supplementary geophysical method, e.g. seismic refraction.

\section{RECONNAISSANCE K/AR DATING OF SAMPLES FROM WEST GREENLAND BETWEEN SØNDRE STRØMFJORD AND FREDERIKSHÅB ISBLINK}

\section{Ole Larsen}

interpretations in collaboration with

Brian F. Windley and V. R. McGregor.

$$
2860 \pm 20 \text { m.y. biotite }
$$

GGU 92133. Epidote gneiss (Finnefjeld gneiss), north of Ilivilik point, east of Napassoq. $65^{\circ} 04^{\prime} \mathrm{N}, 52^{\circ} 15^{\prime} \mathrm{W}$.

This sample represents the typical Finnefjæld gneiss. It is a medium-grained quartz-plagioclase-epidote gneiss with biotite and green hornblende. Microline has been identified as a minor component. Both feldspars are heavily twinned and quartz grains show polygonisation. Biotite, hornblende and epidote are intimately intergrown indicating that the rock has not reached full equilibrium after deformation. Sphene, apatite and opaque ore are all common accessories.

\section{$3117 \pm 40$ m.y. biotite}

GGU 92126. Amphibolite, Qerrulik, east of Napassoq. $65^{\circ} 02^{\prime} \mathrm{N}, 52^{\circ} 20^{\prime} \mathrm{W}$.

The sample is taken from a $1 \mathrm{~m}$ wide discordant amphibolite dyke cutting retrogressed gneisses which contain major relics of granulite facies gneiss. The area represents a transition zone between the retrogressed gneisses of the Fiskefjord region and hornblende-biotite bearing quartz-dioritic gneisses of the Finnefjæld complex.

The rock is fine-grained and consists of twinned plagioclase, unstrained quartz, green hornblende, brown biotite and a little epidote. Accessories are sphene, apatite and opaque ore. 